\title{
EL MILAGRO Y LO COTIDIANO: INTERIORES DOMÉSTICOS Y MOBILIARIO POPULAR EN LOS EXVOTOS ANDALUCES
}

\author{
THE MIRACLE AND THE QUOTIDIAN: DOMESTIC INTERIORS AND POPULAR \\ FURNITURE IN THE ANDALUSIAN VOTIVE OFFERINGS
}

Mar Mercedes Fernández Martín*

Departamento de Historia del Arte. Universidad de Sevilla

\section{Resumen}

A través de la abundante presencia de exvotos pintados en Andalucía occidental se analizan diferentes aspectos de la vida cotidiana como el mobiliario y la presencia que éste tiene en la vivienda, como reflejo de la pertenencia social de sus propietarios. Obras en su mayor parte de autores anónimos y pintores no profesionales, la sencillez e ingenuidad de las pinturas contrasta con la gran cantidad de información que proporcionan. A diferencia del mueble culto, el popular evolucionó más lentamente, pudiéndose afirmar en muchas ocasiones que nos encontramos ante muebles de época indeterminada. De acuerdo con su clasificación cronológica podemos seguir la evolución de sus estructuras y tipologías, así como el cambio de gusto que repercutirá en los temas ornamentales y en la técnica, apreciándose la influencia del mueble culto sobre el popular, o la unión frecuente de ambas expresiones artísticas.

Palabras clave: Exvotos, Andalucía, Interiores domésticos, Mobiliario, Religiosidad popular

\section{Abstract}

Through the abundant presence of votive offerings painted in Andalusia, different aspects of daily life are analyzed, such as furniture and its presence in the home, reflecting the social status of its owners. Works were made, for the most part, by anonymous authors and non-professional painters; the simplicity and ingenuity of the paintings contrast with the large amount of information they provide. Unlike the cultivated furniture, the popular one evolved more slowly, being able to affirm on many occasions that we are dealing with furniture of indeterminate times. According to its chronological classification, we can follow the evolution of its structures and typologies, as well as the shift in preferences that will affect ornamental themes, and technique, appreciating the influence of cultivated furniture over the popular, or the frequent union of both artistic expressions.

Keywords: Votive offerings, Andalusia, domestic interiors, furniture, popular religion 


\section{Introducción}

Los estudios del mueble han evolucionado considerablemente en las últimas décadas, aunque su historia, desde el punto de vista patrimonial, sigue siendo reciente. Esto se hace mucho más evidente en el caso del mueble popular y el espacio privado donde se ubica, que ha sido relegado y, desgraciadamente, ha pasado desapercibido para la Historia del Arte. El mobiliario que se conserva y se muestra en los museos es el mobiliario de las clases privilegiadas, mientras que el utilizado por el pueblo se ha perdido en la mayoría de las ocasiones, por lo que el estudio completo y sistemático del mueble popular está todavía por hacer. ${ }^{1}$ No obstante, a diferencia del mueble culto, el popular evolucionó más lentamente, pudiéndose afirmar en muchas ocasiones que nos encontramos ante muebles de época indeterminada. De acuerdo con su clasificación cronológica podemos seguir la evolución de sus estructuras, es decir, la forma y tipología del mueble, así como el cambio de gusto que repercutirá en los temas ornamentales y en la técnica. Con ello se puede detectar la influencia del mueble culto sobre el popular, incluso la unión frecuente de ambas expresiones artísticas. ${ }^{2}$

Para su estudio hay que valerse de fuentes complementarias o secundarias como la literatura y la pintura pues, por sus características, este tipo de muebles apenas queda reflejado en la información recogida en los archivos debido a que, por regla general, el pueblo llano genera menos información documental. En las escasas ocasiones en que aparece representado el mobiliario en la pintura español lo hace como referencia espacial, pero sin dedicarle atención como tales muebles. ${ }^{3}$ La excepción la encontramos en los exvotos narrativos o pictóricos, exponentes de la devoción popular que, a pesar de sus límites, son una fuente importante de conocimiento de la cultura material de una época, máxime cuando, como se ha señalado, la pintura española es muy parca a la hora de mostrar los interiores domésticos.

Hasta hace relativamente poco tiempo los exvotos han merecido escasa atención desde el punto de vista patrimonial y artístico, insistiéndose principalmente en su valor antropológico y sociológico, como reflejo de la religiosidad popular. ${ }^{4}$ No obstante, hay que tener presente que son también una importante fuente de información histórica y artística pues a través de ellos se puede reconstruir la forma de vida y costumbres del pueblo llano. Afortunadamente, el valor documental, artístico, histórico y etnográfico del exvoto ha sido reconocido, lo que obliga a las instituciones a desarrollar una política proteccionista y de restauración para frenar la pérdida o deterioro que han sufrido a lo largo de los años. ${ }^{5}$

\section{Exvotos narrativos}

Antes de analizar los interiores que se representan en estos cuadros es conveniente indicar algunas generalidades que ayuden a comprender mejor el sentido de los mismos, como formas de expresión religiosa, ampliamente difundidas entre las clases populares, aunque no fueran exclusivos de ellas. ${ }^{6} \mathrm{El}$ significado de ex voto, o "por voto", se entiende que es la ofrenda hecha en señal y recuerdo por un beneficio recibido, pudiéndose distinguir entre los simbólicos, 
aquellos que reproducen objetos concretos, y los narrativos. ${ }^{7}$ Estos últimos reflejan el relato del percance o enfermedad sufrida y el desenlace de la situación, es decir, la curación por intercesión divina, conservándose una gran variedad de este tipo repartidos por los numerosos santuarios andaluces, donde el donante verifica a través de un pequeño cuadro pintado el suceso. El objetivo principal fue, sin duda, el agradecimiento, pero también dejar constancia del suceso a través de la intercesión celestial. De esta forma, en cuanto a sus aspectos formales, como muestra de la religiosidad popular, concurren dos elementos a tener en consideración: por un lado, la devoción del promotor hacia la imagen sagrada representada y, por otro, la muestra de agradecimiento por el favor recibido.

Desde el punto de vista artístico este tipo de exvotos se les puede catalogar como obras "de serie". Son pinturas, generalmente medianas o pequeñas, en formato horizontal, ejecutadas con una técnica sencilla y con un estilo ingenuo. Como tales pinturas presentan las mismas características formales que las obras pictóricas, es decir, requieren un soporte y necesitan una técnica. En realidad, siguen en la mayoría de las ocasiones, las directrices de la "pintura culta", con planteamientos similares a los rompimientos de gloria de la pintura religiosa, diferenciando claramente dos espacios: el divino y el terrenal. No obstante, el pintor no se propone hacer una obra de arte como tal sino relatar un acontecimiento del modo más claro posible, poniendo en evidencia la protección celestial, pero sin olvidar todos los detalles, minuciosamente representados. No obstante, los objetos que se representan no son los protagonistas, puesto que lo que interesa al donante es no distraer la atención del espectador de la figura o escena que se representa.

Las escenas suelen guardar el mismo patrón y están estructuradas en tres zonas bien definidas: por una parte la representación de la imagen devocional a la que se implora, que reproduce fielmente la advocación, apreciándose los cambios de gusto en el arreglo de las imágenes a lo largo de los años; por otra la escena propiamente dicha, donde se representa la petición o agradecimiento por el favor recibido y, por último, el texto que a veces se obvia o queda relegado a un espacio secundario, pero sendas partes constituyen la unidad conceptual que conforma un exvoto. En otras ocasiones también nos muestran otras advocaciones recogidas en cuadros, por lo que podemos hablar del cuadro dentro del cuadro y que permite reconstruir el ambiente de religiosidad doméstica de la época. ${ }^{8}$ (fig.1)

Los más antiguos están pintados sobre tabla, por regla general sin una capa de preparación previa, pero también son muy numerosos los que están pintados sobre lienzo, cartón, papel, hojalata, etc. Por regla general, presentan un formato rectangular, apaisado, el más adecuado a la hora de narrar la escena. El pigmento empleado suele ser el óleo y a veces se utiliza la técnica del collage, al sobreponer alguna estampa devocional. Como se ha señalado, estos pequeños cuadros unen a su valor estético, como expresión de arte popular, el valor histórico y descriptivo de las costumbres populares de épocas pasadas que de otra forma habrían desaparecido o sería muy difícil reconstruir.$^{9}$

Por lo general los exvotos son anónimos, realizados por encargo, existiendo incluso artesanos autodidactas especializados en este tipo de pinturas, quienes reproducen la realidad lo mejor que saben. El artista conocedor, o no, 
de las normas de perspectiva, plasma la escena tal cual la ve o la imagina, tratando que su obra resulte un auténtico documento, pero no dejan de ser escenas muy planas y con escasa gradación del color. En este sentido la pintura es muy realista y muestra un gran interés por los detalles, aunque a veces distorsionan la realidad de forma voluntaria. ${ }^{10}$ Partiendo del hecho de que hay que representar sobre una superficie las tres dimensiones del espacio, en los casos en que el artista tiene una mayor preparación, aquella se logra por el método convencional de las líneas de perspectiva. Por el contrario, en aquellos otros en que el autor carece de formación, el resultado obtenido es desigual, recordándonos, aún sin proponérselo, a soluciones de perspectiva totalmente ingenuas. A veces son las vigas del techo o la solería las que sirven para marcar la perspectiva a través de las líneas de fuga pintadas más oscuras o la propia disposición de los muebles, a veces colocados en forzados escorzos. La percepción espacial es muy amplia, con pequeños objetos que dimensionan la estancia. Por regla general, en la mayoría de las ocasiones, las habitaciones que se representan son fruto de la imaginación del artista por lo que es probable que el autor inventara algunos elementos, siendo frecuente que en algunos santuarios se repita el mismo interior en exvotos de fechas diferentes. El mobiliario aparece solo como un mero pretexto o decorado, no obstante, no dejan de ser referencias reales del entorno del autor de las pinturas pues, a través de estas pinturas, podemos analizar el espacio arquitectónico, así como los materiales de construcción empleados, el mobiliario y la decoración. ${ }^{11}$ Los objetos se reproducen no por lo que son sino por lo que representan pero, además, nos muestran la cotidianeidad, como las costumbres o la forma de vestir, detalles que reflejan el status social y económico de sus propietarios.

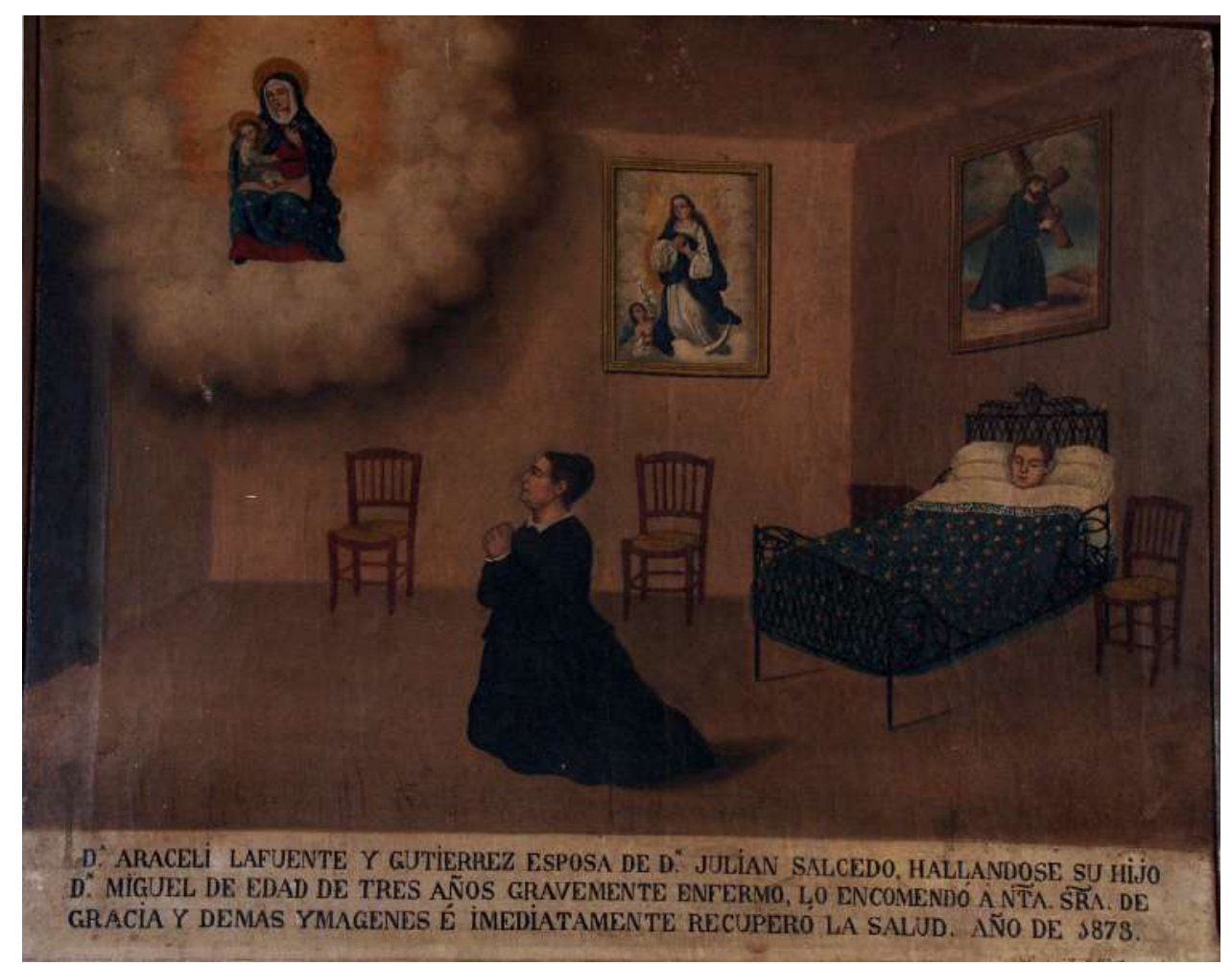

Fig. 1 Santuario de Nuestra Señora de Gracia. Archidona (Málaga) 
Respecto a las devociones, el fervor religioso y en particular el mariano, tiene en Andalucía un claro exponente en el papel que jugó en la mediación de las enfermedades. Son muy abundantes los exvotos conservados, repartidos por toda su geografía, dándose en algunos santuarios o ermitas una alta concentración. Destacan los sevillanos de San Benito en Castilblanco de los Arroyos, Virgen de Consolación de Utrera y Cristo de Torrijos en Valencina de la Concepción; los cordobeses de Santo Domingo de Scala Coeli, Nuestra Señora de Linares y Virgen de la Fuensanta, el de la Virgen de Belén en Montilla y el de Nuestra Señora del Valle en Santaella; los gaditanos de Nuestra Señora de los Santos en Alcalá de los Gazules, la Virgen de Regla en Chipiona y Virgen de los Remedios de Olvera; el malagueño de la Virgen de Gracia de Archidona; los onubenses de la Virgen del Valle en Manzanilla y del Rocío en Almonte; los almerienses de la Virgen del Saliente en Albox y Cristo de la Yedra en Vélez Rubio, o el santuario jiennense de la Virgen de la Cabeza en Andújar, sin que con ellos se cite la totalidad de los santuarios andaluces que conservan exvotos pictóricos. No obstante, se observa un claro predominio de los exvotos conservados en las provincias occidentales sobre las orientales, donde los exvotos pintados son más escasos. ${ }^{12}$

Los que se conservan se fechan en su mayor parte en los siglos XVIII y XIX, periodo en el que este modo de expresión de la religiosidad popular andaluza alcanza su apogeo, para ir decayendo a comienzos del XX y, lamentablemente, perdiéndose muchos de ellos. En ellos se reflejan los interiores de las viviendas, por regla general viviendas humildes, donde el mobiliario es escaso. Muebles populares como sillas de asiento de enea, camas de madera o de hierro, nos hablan de una artesanía local llena de tradiciones libremente interpretadas, aunque a veces derivados de estilos oficiales de los que se hace una original mezcla. Con menos frecuencia nos muestran otros muebles como consolas, bancos o cunas, que siguen a menor escala el mismo modelo que las camas, y raras veces alfombras o armarios. La sencillez e ingenuidad de las pinturas contrasta con la gran cantidad de información que proporcionan, pudiéndose considerar auténticos documentos gráficos, cargados de información de gran valor. A través de estas pinturas podemos "entrar" en las viviendas, reflejo de sus propietarios, y observar las pervivencias y evolución que experimentó el mobiliario, principalmente las camas y las sillas que son los muebles mejor representados.

\section{Mobiliario y ambientación}

Las viviendas en el Antiguo Régimen no estaban bien acondicionadas en el ámbito rural, sólo se limitaban a satisfacer las necesidades básicas, sin ningún lujo y sin comodidades. Los avances y variaciones comienzan a notarse a finales del siglo XVIII, pero el inmovilismo y las permanencias y tradiciones van a perdurar en los estratos sociales más populares. En 1756, un viajero anónimo que visitó España escribía:

... Los mobiliarios de las casas son tan mezquinos como los vestidos. No hay mayor comodidad, nada bien distribuido, ningún bienestar; no utilizan las chimeneas; no queman leña ... las paredes son blancas y 
solamente cubiertas con cuadros de devoción; el suelo está cubierto de esteras y las sillas son de paja. De ahí, excepto las casas de los grandes y de algunas gentes ricas que han viajado, el mueblaje ordinario de España. ${ }^{13}$

Las transformaciones en la tendencia al confort, el aumento de la decoración y la variedad tipológica del mobiliario no se van a apreciar hasta después de la Guerra de la Independencia. Se experimenta entonces un cambio de las modas, la importancia de la apariencia, el nivel cultural y la amplitud simbólica de horizontes de los distintos grupos sociales, especialmente en los ámbitos urbanos donde la burguesía comienza a tener un papel preponderante, no reflejándose esta evolución en los ámbitos más populares.

La estancia con más frecuencia representada en los exvotos es el dormitorio o alcoba, lugar donde yace el enfermo por el que se solicita el auxilio divino. Si bien hay que tener presente que el dormitorio era un lugar multifuncional pues no estaba considerado estrictamente como lugar en el que se duerme, pudiéndose utilizar cualquier espacio en el que existiera algo parecido a una cama. La variedad de camas que se citan en la literatura es abrumadora y su comodidad y complementos son rasgos que definen la riqueza o pobreza de sus propietarios. Desde un jergón con mantas a camas de maderas nobles, pasando por camas de viaje, encajadas, etc. No es hasta el siglo XVIII cuando aparece la alcoba, entendida como un pequeño pabellón separado en un rincón de la estancia, obedeciendo siempre al gusto por lo privado y lo íntimo, con lo que se preludia el dormitorio moderno. Las dimensiones de las camas se habían ido reduciendo desde el Renacimiento como consecuencia de la progresiva limitación de los espacios internos del hogar, y se fueron acomodando con mayor rigor a las proporciones de los individuos a lo largo de los siglos.

En el amplio número de exvotos analizados el dormitorio es un espacio amplio donde la cama, o la cuna, son casi el único mobiliario de la estancia, disponiéndose adosadas a la pared, junto a algunas sillas dispuestas en el frente y, en ocasiones, algún cuadro con paisajes o tema devocional. En la representación de viviendas más humildes se muestran habitaciones deficientemente aireadas, donde, excepcionalmente, aparece una pequeña ventana o una puerta entreabierta. El dormitorio se muestra como un espacio flexible donde se pueden desarrollar diferentes actividades, además de la del descanso. En función de ello variarán los muebles y adornos que, a su vez, reflejan el estatus social y económico de sus propietarios. ${ }^{14}$

Como se ha señalado, sin lugar a duda, la cama es la gran protagonista, mueble que experimenta una notable transformación, adaptándose a las modas imperantes. Por regla general las camas son medianas, ocupadas por una única persona, máxime cuando la cama de matrimonio no se populariza hasta mediados del siglo XIX. Las camas que se representan son a la española, es decir aquellas de cabecero alto y piecero bajo que se arrima a la pared por el primero, diferenciándose así de las camas a la francesa o de sofá, arrimadas a la pared por uno de los laterales. ${ }^{15}$ Se representan modelos que abarcan desde una sencilla cama o catre sin cabecero, donde el ajuar textil tiene un importante protagonismo, con colchas coloridas, almohadas y embozos de encajes y bordados, a camas que siguen los modelos imperantes y que recogen las influencias 
del mueble culto, muebles derivados de los estilos oficiales de los que hacen una curiosa interpretación. (fig. 2)

El ejemplo de cama más antiguo lo encontramos en un exvoto ofrecido a la Virgen de Gracia en Archidona (Málaga), fechado en 1790. En él se representa una estancia que se repite en exvotos posteriores, donde el protagonismo lo tiene la imagen devocional que ocupa el tercio izquierdo de la composición. En el centro de la estancia una madre muestra a su hijo en brazos y tras de ella un balcón con puerta de doble hoja, con un postigo abierto, lo que da profundidad a la composición, y cortina con su galería dorada. La decoración se complementa con tres cornucopias doradas, pintadas con todo lujo de detalles y una cama de cabecero alto, de perfil mixtilíneo recortado, rematado por un penacho y una cartela central, perfilado todo en dorado, de gusto rococó, que reproduce modelos propios de la segunda mitad del siglo XVIII. (fig. 3)

Este tipo de camas fue muy frecuente durante el siglo XVIII, desarrollándose en el Levante peninsular un tipo de cama con personalidad propia, cuyos centros de producción principales se hallaron en Olot, Vich, Valencia y Mallorca, conociéndose actualmente como camas de Olot. ${ }^{16}$ Estas se caracterizan por sus grandes cabeceros, en general de forma más o menos piramidal, que se estucaban y se pintaban. Irán evolucionando y más tarde aparece la pata cabriolé, que se prolonga hacia arriba formando postes a media altura, también en cabriolé, como se aprecia en varios exvotos de la ermita de la Virgen de Gracia de Archidona (Málaga). El cabecero solía ser exento, fijado directamente sobre la pared, realizado con maderas blandas como álamo blanco o negro y el abedul, estando los más antiguos policromados en un solo color o jaspeados con los perfiles en dorado. A partir del segundo cuarto del siglo XVIII, surgen las imágenes religiosas insertas en una reserva de contornos ondulados y a finales de la centuria las patas y los postes se tornean y los motivos decorativos que se representan en las cabeceras se tornan cortesanos, aligerándose los perfiles de motivos rococós. Por regla general los modelos del último tercio de siglo van a perdurar durante largo tiempo caracterizándose por camas con cabecero alto, unido por largueros a un piecero constituido por dos columnas rematadas por florones, similares a los que coronan las dos pilastras que flanquean el cabecero, a veces cubierto con pabellón que colgaba del techo y del cual, a su vez pendían las cortinas.

Durante el primer tercio del siglo XIX el estilo Imperio va a triunfar plenamente en los interiores burgueses, reflejándose también en ambientes más humildes. Las camas de madera con cabeceros de copa, más o menos decorados con tallas, reflejan la influencia del estilo, como se aprecia en diferentes exvotos, como en el ofrecido por doña Josefa Morán al Señor de la Salud, donde el cabecero responde a esos modelos que tanto desarrollo alcanzaron en Cataluña. (fig. 4) En este periodo la cama va a copiar modelos anteriores, pero también se van a introducir nuevas modas como se aprecia en los cabeceros que, con interpretaciones más o menos fieles a los modelos originales, reinterpretan el alto cabecero, unido por largueros a un piecero rematado por dos montantes no muy altos. El cabecero lo forman dos rectángulos superpuestos o en forma de peineta, coronados por un frontón, mientras que el piecero queda reducido a los dos montantes en forma de semicolumnas. 


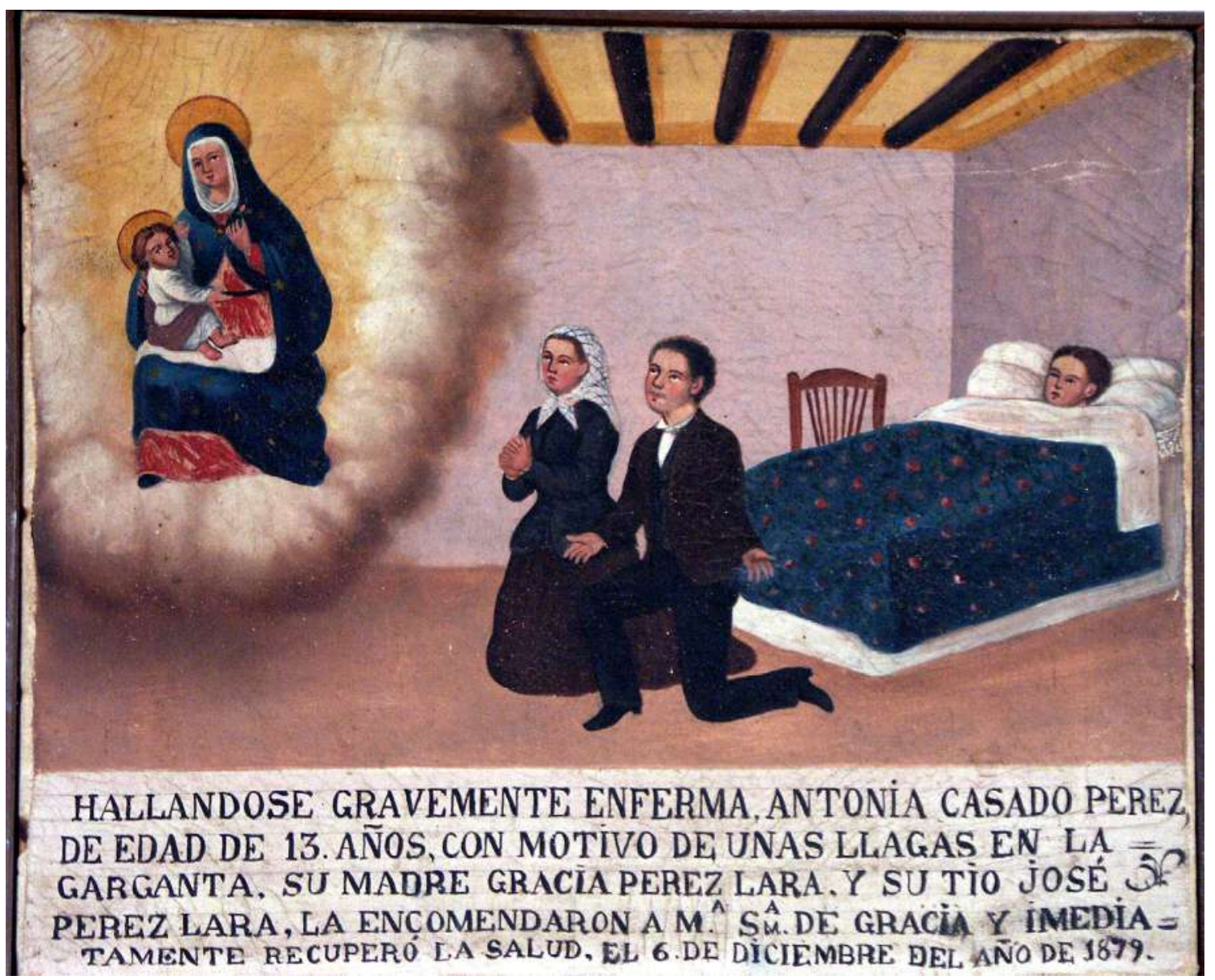

Fig. 2 Santuario de Nuestra Señora de Gracia. Archidona (Málaga)

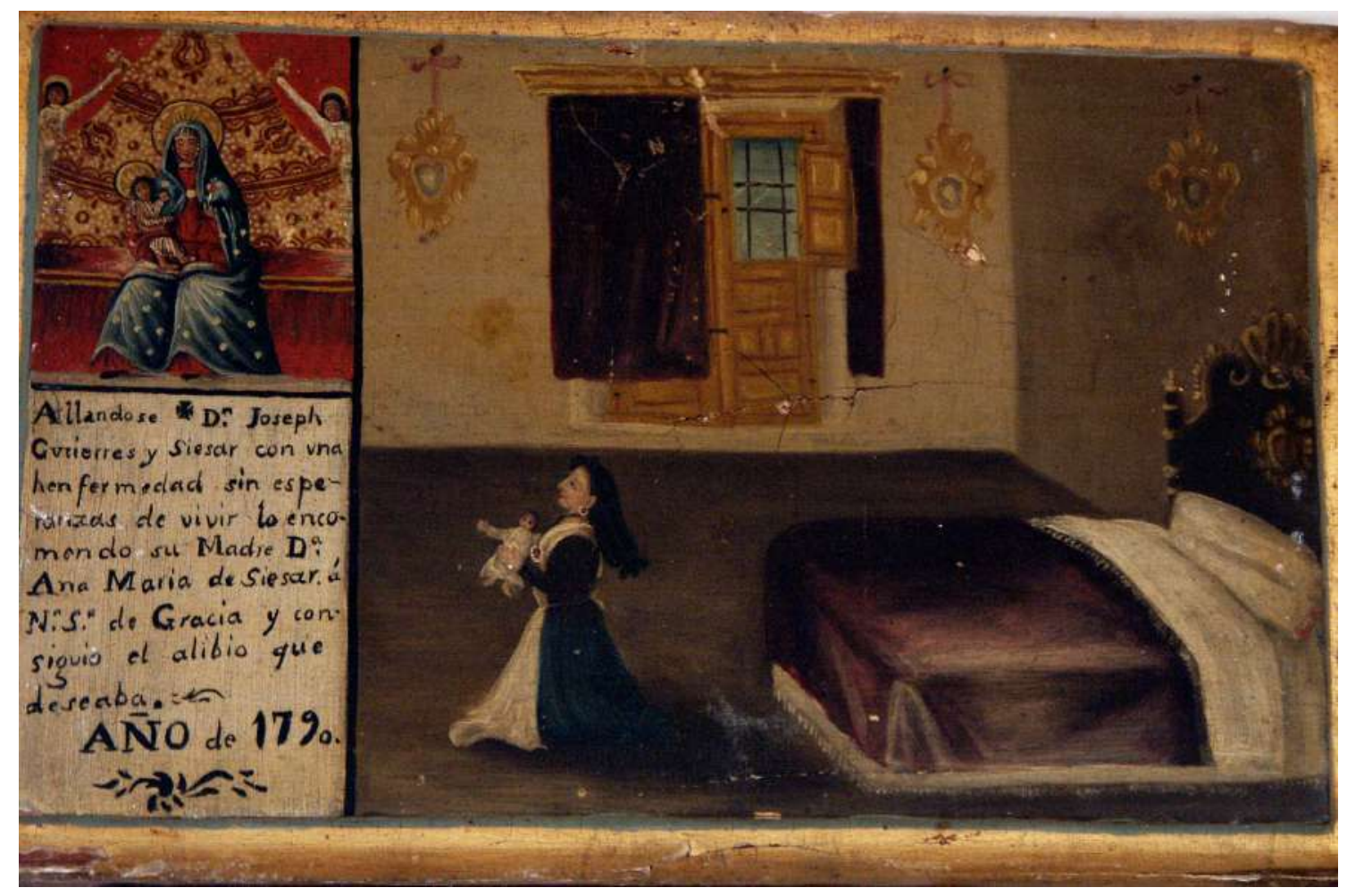

Fig. 3 Santuario de Nuestra Señora de Gracia. Archidona (Málaga) 


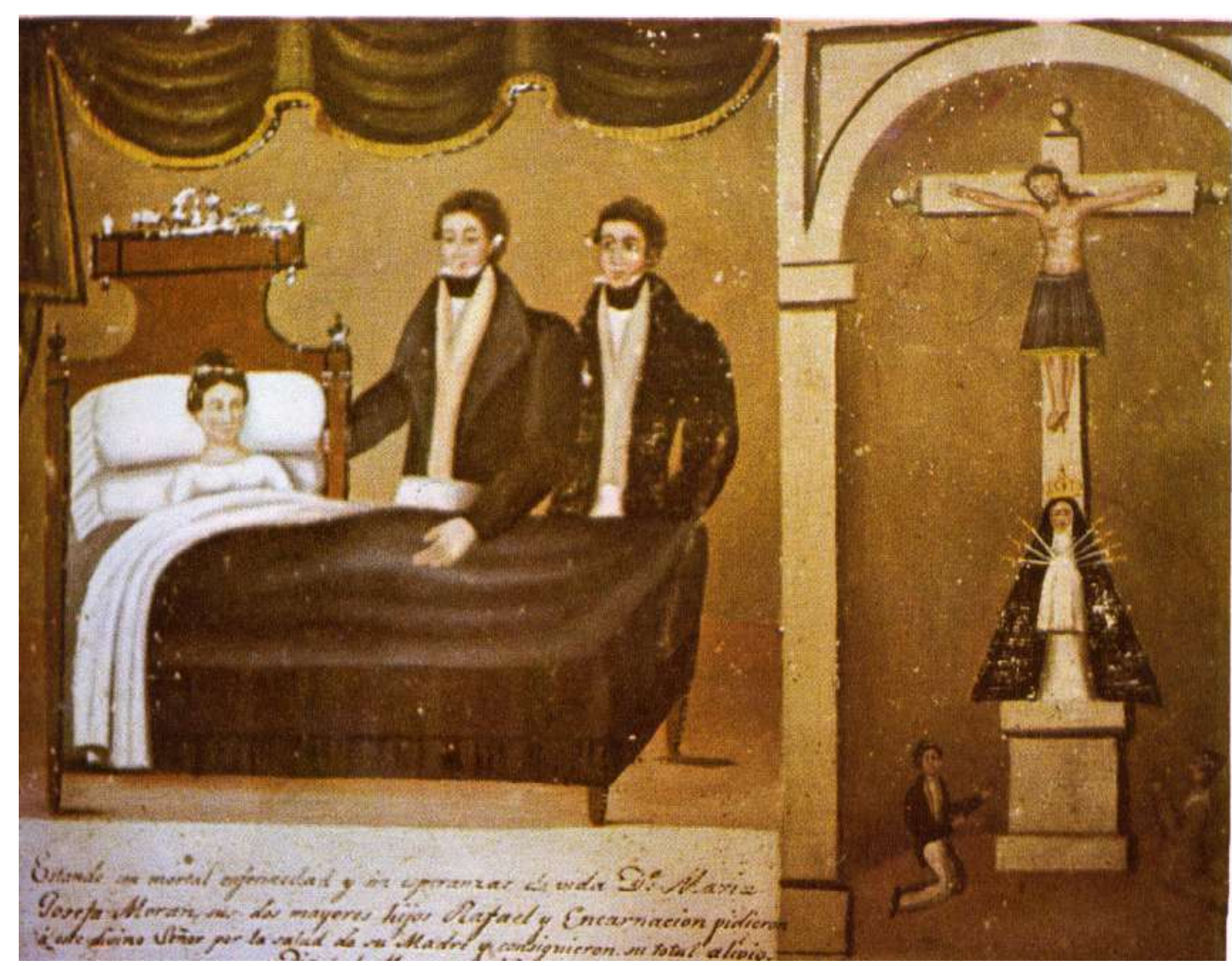

Fig. 4 Santuario de Nuestra Señora de Consolación. Utrera (Sevilla)

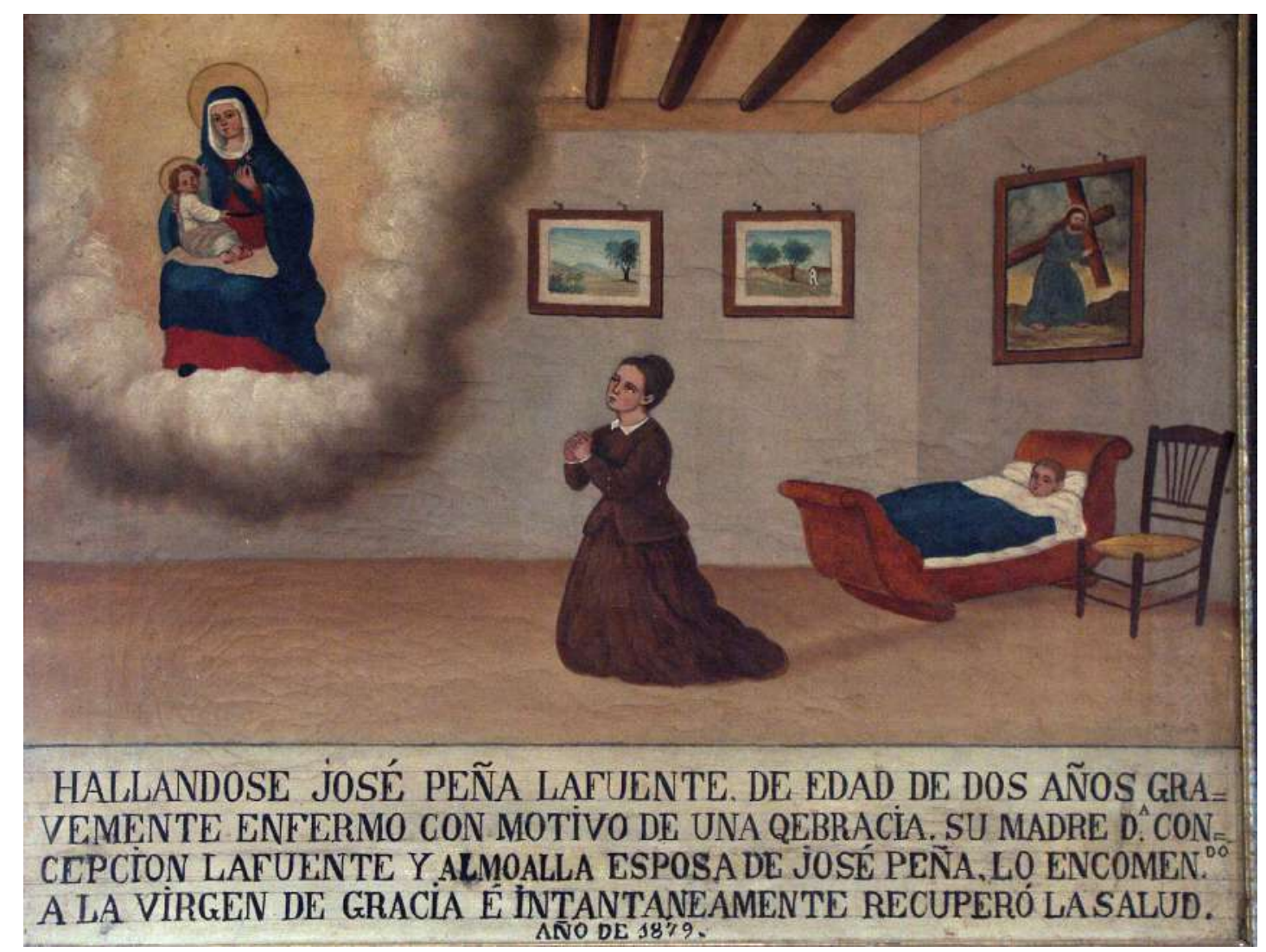

Fig. 5 Santuario de Nuestra Señora de Gracia. Archidona (Málaga) 
La influencia del estilo Imperio en la cama fue muy duradera, manteniéndose a lo largo de toda la centuria. En los años centrales del siglo en el estilo Isabelino, coincidente con el Neorrococó francés o el Victoriano en Inglaterra, tuvo amplio desarrollo la cama de barco o cama góndola, con el cabecero y el piecero de la misma altura y extremos ligeramente curvados hacia el exterior. Este modelo que surge en Francia en el Neoclasicismo tardío, transposición directa de la lit de bout, fue un modelo muy demandado en la segunda mitad de la centuria y rápidamente aceptado por la burguesía. Este mismo modelo de góndola o barco se utiliza también en las cunas, donde se reproduce el mismo modelo a menor escala. La aceptación de este modelo en Andalucía queda reflejada en varios exvotos que, a pesar de representar interiores humildes, la cama o la cuna reproduce modelos burgueses. (fig. 5) A pesar de la alta mortalidad infantil de la época son relativamente pocas las escenas solicitando favores a niños. Cuando estos aparecen en el lecho, bien lo hacen en la cama de los mayores o se representan cunas que imitan a aquellas, colocándole unas barandillas como las que se reproducen en varios exvotos, con barrotes torneados, modelos populares y atemporales.

El dormitorio sufre alteraciones en los últimos años del siglo XIX, por un lado, en lo referente al cambio de los estilos, pero también a un incremento de muebles auxiliares como mesillas de noche, palanganeros o armarios, a lo que hay que sumar nuevos materiales y técnicas constructivas. El más permanente de la serie de estilos que impera en España entre los años 1850 y 1865 es el denominado Isabelino que, en definitiva, no es más que la mezcla de las líneas y adornos que caracterizaron a los muebles Luis XIV y Luis XV. En este período el dormitorio de una casa acomodada contaba con la cama, como elemento esencial, mesitas de noche, tocador, lavabo, e incluso biombos, muy usuales en el siglo XIX, a los que hay que sumar el armario de luna que se populariza a finales del siglo.

Una innovación importante fue la sustitución de las camas de madera por las metálicas que empezó hacia 1840 en Inglaterra, generalizándose a partir de la Gran Exposición Universal de Londres de 1851, donde se expusieron algunos modelos. Relegadas en un principio a hospitales, prisiones o cuarteles, poco a poco hicieron su aparición en el ámbito doméstico. Las razones de su gran aceptación fueron principalmente las higiénicas pues las chinches y otros insectos obligaban a desmontar, al menos una vez al año, las camas de madera. En España, en la década de 1870, ya estaban muy extendidas, cuando el hierro colado sustituyó a la forja manual. A finales de siglo Sevilla contaba con varias fábricas de camas de hierro, como la de José Cobián Rual o la de la Viuda de Urquiza que abastecieron a toda Andalucía occidental. ${ }^{17}$ A pesar de que el uso del metal puede propiciar formas más simples, los ejemplos que se reflejan en los exvotos son muy variados. Así, alrededor de la estructura básica horizontal de la cama, se siguieron utilizando doseles, columnas y baldaquinos, ricamente forjados y ornados, para proteger al usuario del frío, de los insectos, etc.

La aceptación que tuvieron las camas de estructura metálica en el ámbito andaluz se refleja en numerosos exvotos que reproducen un número considerable de camas de hierro, algunas muy similares a los diseños que se presentaron en la Gran Exposición de Londres, ${ }^{18}$ como la cama que aparece en un exvoto 
dedicado a la Virgen de Nuestra Señora de los Santos de Alcalá de los Gazules, con un pabellón que se remata con una corona. (fig. 6) Idénticas características se aprecia también en otro de 1879 donde la estructura metálica se cubre con un dosel de encaje recogido en el centro por una corona.

A principios del siglo XX las camas dejan de ser tan aparatosas y los dormitorios presentan un mayor número de muebles. Además de la silla y la cama, casi el único amueblamiento existente hasta el momento, aparecen nuevos muebles como la mesilla de noche, alguna cómoda y el lavabo, con el complemento en las paredes de algún cuadro de devoción. En el menor de los casos aparece alguna ventana o puerta cubierta por cortinas, resultando espacios bastante oscuros. Las mesillas se sitúan a la altura de la cabecera. Las más sencillas son bajas y sin ninguna decoración, como mucho un cajón frontal. No obstante, en exvotos más tardíos aparece un tipo de mesilla que pervivió largamente en los dormitorios andaluces. De proporciones más altas y estrechas, con tapa de mármol, con cajón frontal y una portezuela inferior para contener la bacina $u$ orinal. (fig. 7)

Antes de la difusión de la fontanería era frecuente en los dormitorios el lavabo o palanganero, estructura de madera o hierro de unos 85 centímetros de alto donde se colocaba la palangana para asearse. Se componía de un cerco donde encajaba el recipiente, prolongándose en los extremos en forma de asas donde se colgaban las toallas. En la parte inferior se disponía una plataforma para colocar la jarra con el agua. El conjunto se completaba con un espejo enmarcado por la prolongación de las patas traseras. Aunque fue muy usual en los dormitorios de fin del Ochocientos, en los exvotos analizados no son muy frecuentes a excepción de los localizados en la ermita de Nuestra Señora de los Santos de Alcalá de los Gazules (Cádiz), de los más descriptivo en cuanto al mobiliario de una alcoba en esos años. ${ }^{19}$ (fig. 8)

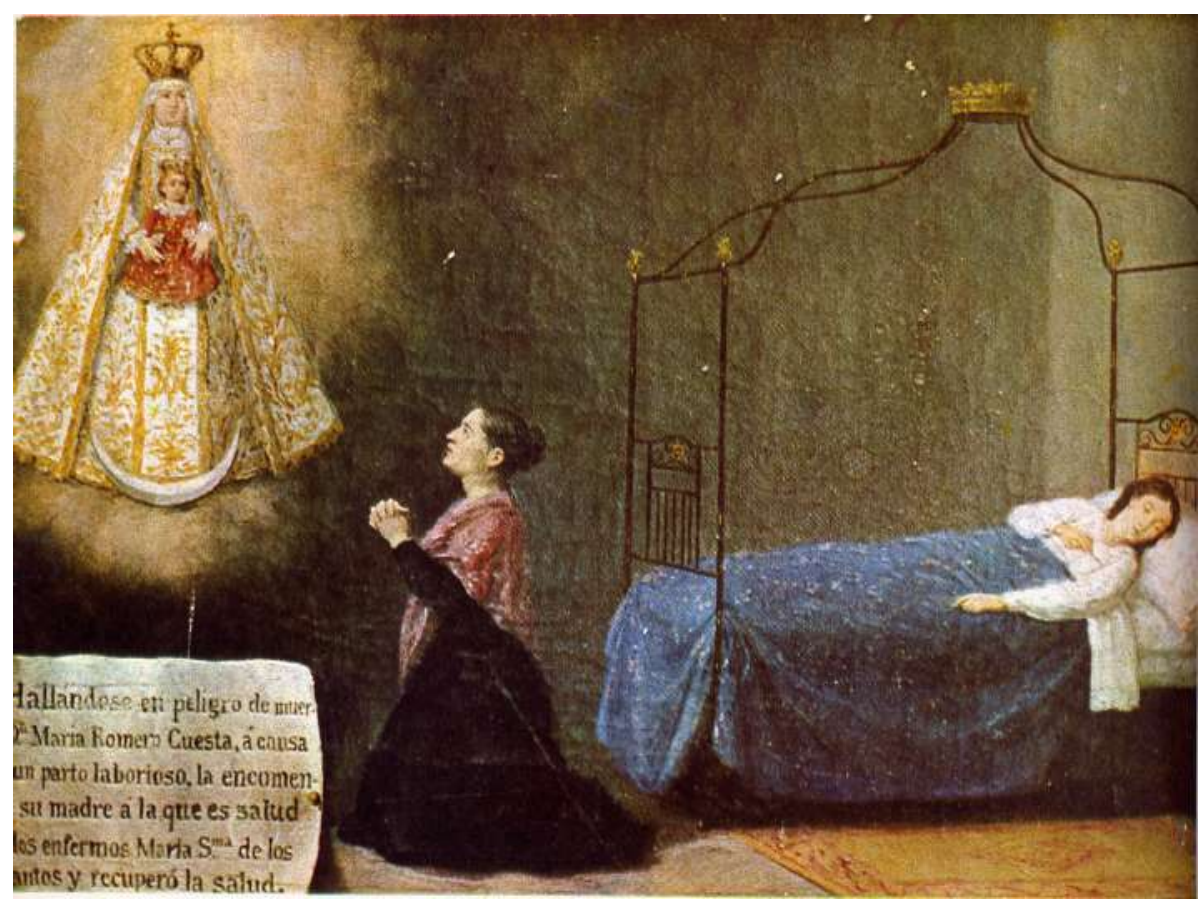

Fig. 6 Santuario de Nuestra Señora de los Santos. Alcalá de los Gazules (Cádiz) 


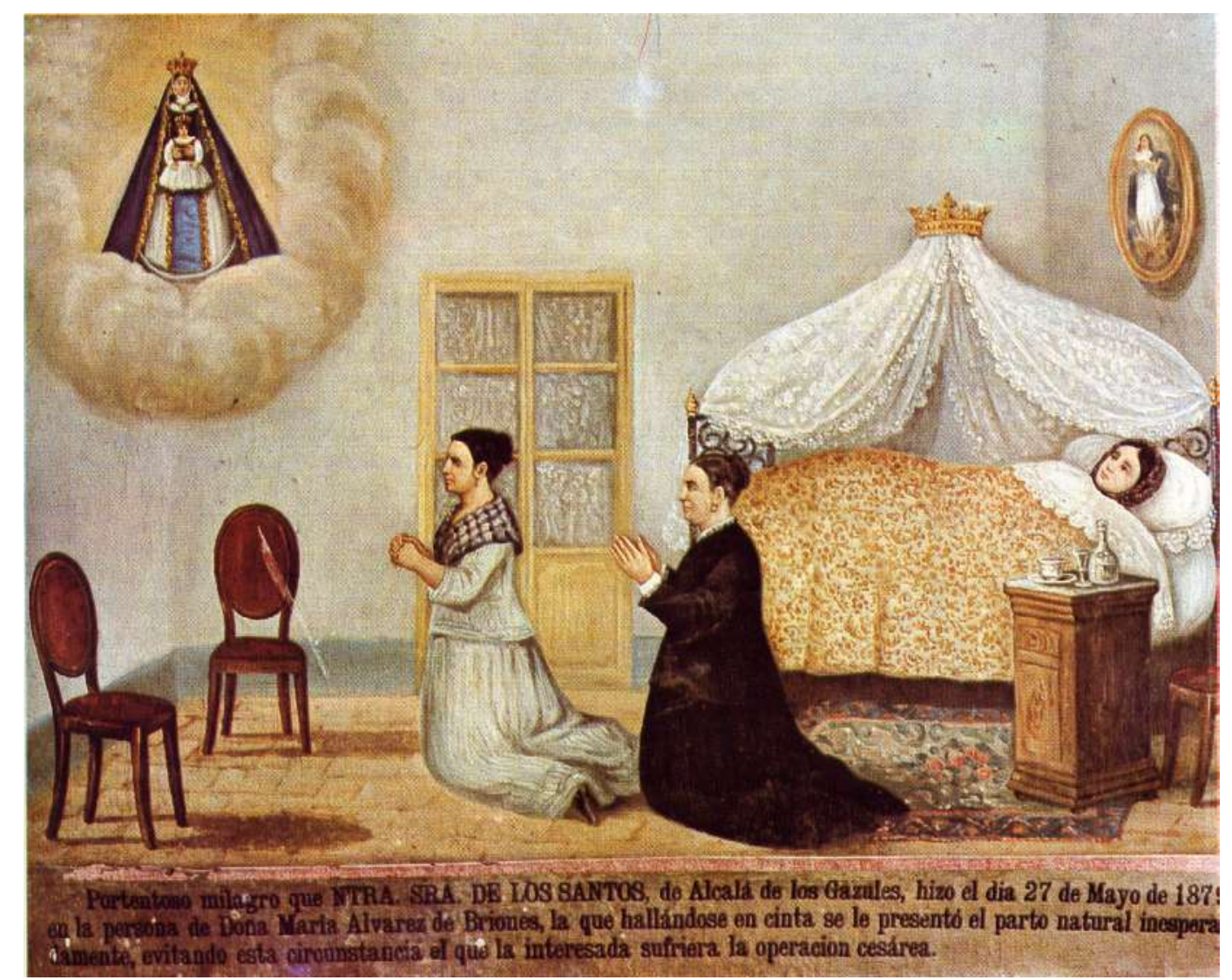

Fig. 7 Santuario de Nuestra Señora de los Santos. Alcalá de los Gazules (Cádiz)

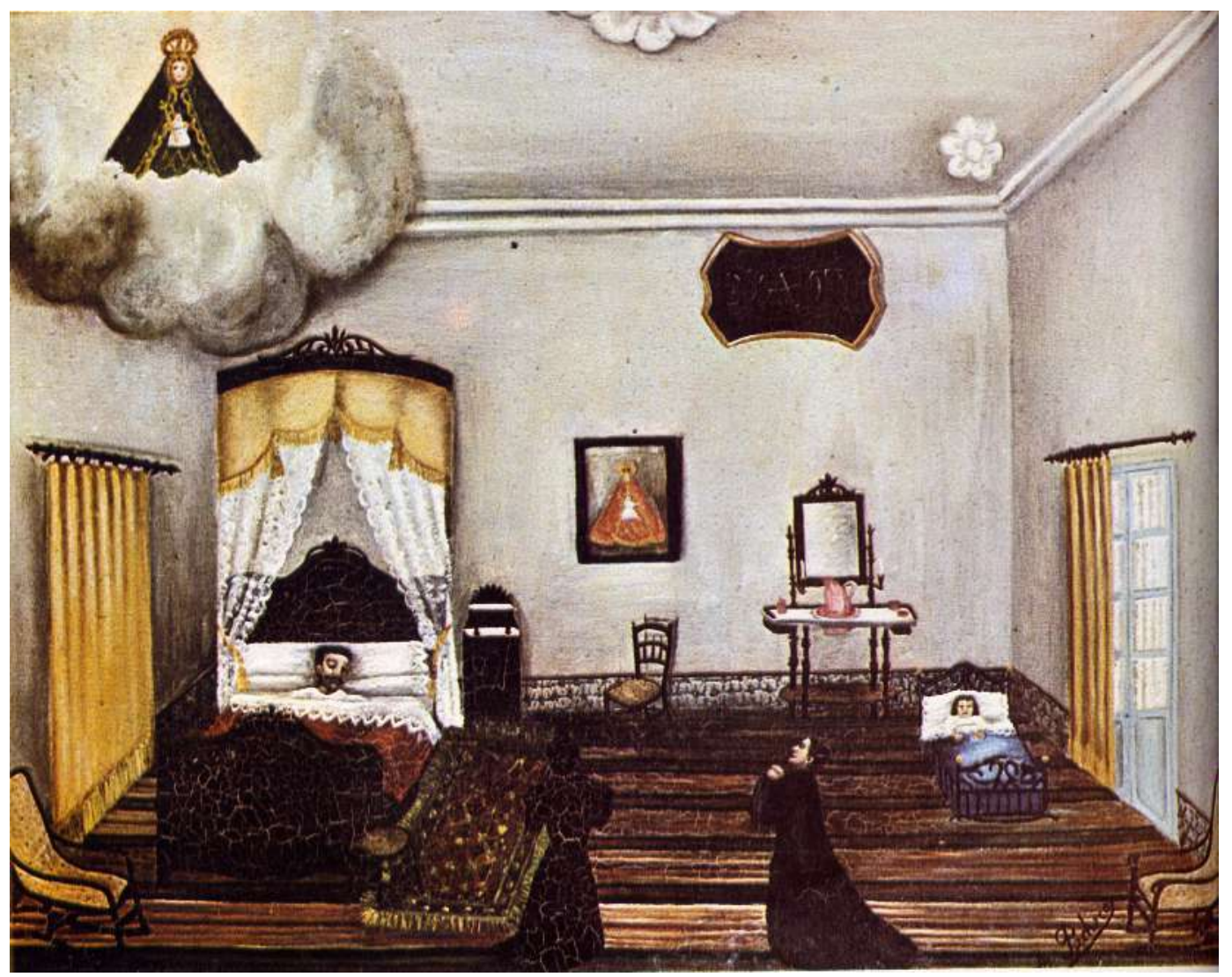

Fig. 8 Santuario de Nuestra Señora de los Santos. Alcalá de los Gazules (Cádiz) 
La cómoda fue el mueble más popular de la época, adaptándose a cualquier espacio de la casa, aunque en un principio estaban destinadas a salas y comedores, también se usaron en el dormitorio. Su producción fue amplia y muy frecuente en los hogares burgueses de fines del siglo XIX. De formas rectas y de marcada verticalidad, descansa sobre un zócalo o patas cortas, el frente está ocupado por un número variable de cajones, siendo los centrales de mayor tamaño que el primero y el último, a veces divididos en dos. (fig. 9) Menos frecuentes fueron los armarios que, aunque hacen su aparición a mediados del siglo XIX en las casas burguesas, en las de las clases más humildes o populares no van a ser frecuentes hasta el siglo XX, con la aparición del armario de luna. Como hemos visto el dormitorio tiene todo el protagonismo en los exvotos andaluces. Menos frecuentes es que se representen otras estancias de la casa, por lo que el mobiliario queda reducido a la cama, sillas y algún cuadro. En algunas ocasiones se representa un espacio poco definido que podría interpretarse como una sala. Este es el caso del exvoto dedicado a la Virgen de Gracia de Archidona (Málaga), realizado en 1791. En el centro de la estancia se representa a una joven sentada en una silla y tras de ella a una señora mayor, ambas ataviadas con ricos vestidos a la moda de la época, con pelucas empolvadas y joyas como las manillas, tan características de la época. En él se representa un interior lujosamente adornado con cuadros con marcos ricamente tallados y dorados al igual que las cornucopias doradas con espejos para la reverberación de la luz. Una puerta de dos hojas y postiguillo, rematada con una galería con copete central de la que cuelga una cortina azul celeste recogida a cada lado por medio de abrazaderas da profundidad a la estancia. Arrimadas a la pared están colocadas dos sillas de estilo inglés, Reina Ana, con patas cabriolé y marcada rodilla. El respaldo calado de pala central en forma de pala decorada con marquetería. ${ }^{20}$ (fig. 10)

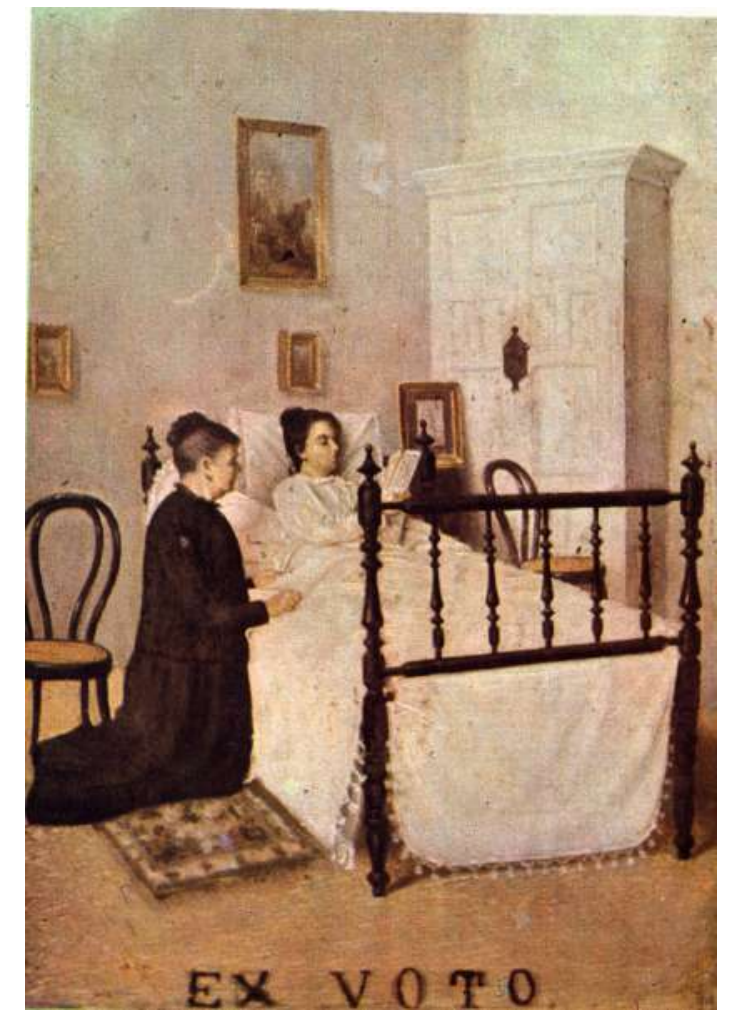

Fig. 9 Santuario de Nuestra Señora de Regla. Chipiona (Cádiz) 


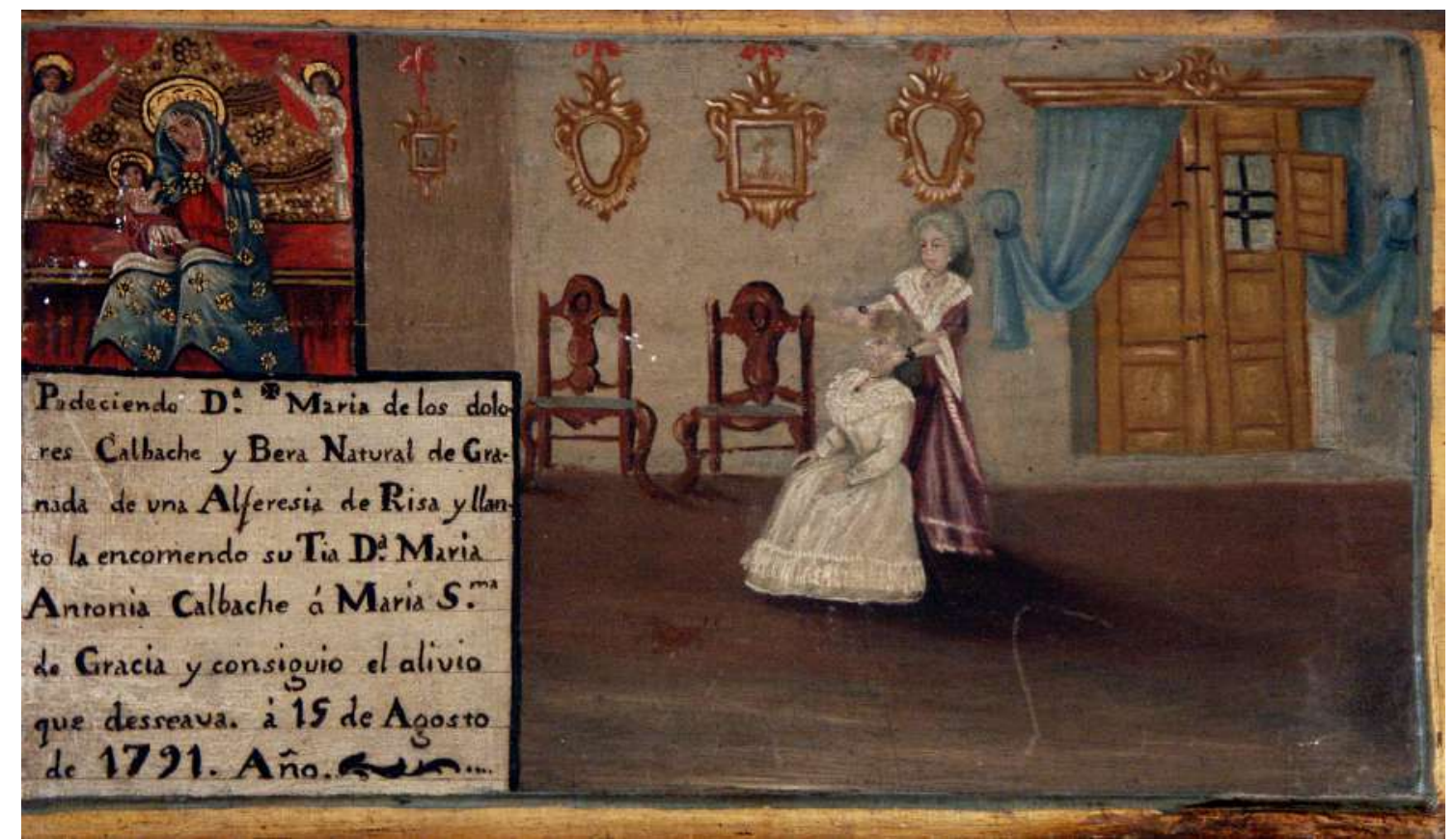

Fig. 10 Santuario de Nuestra Señora de Gracia. Archidona (Málaga)

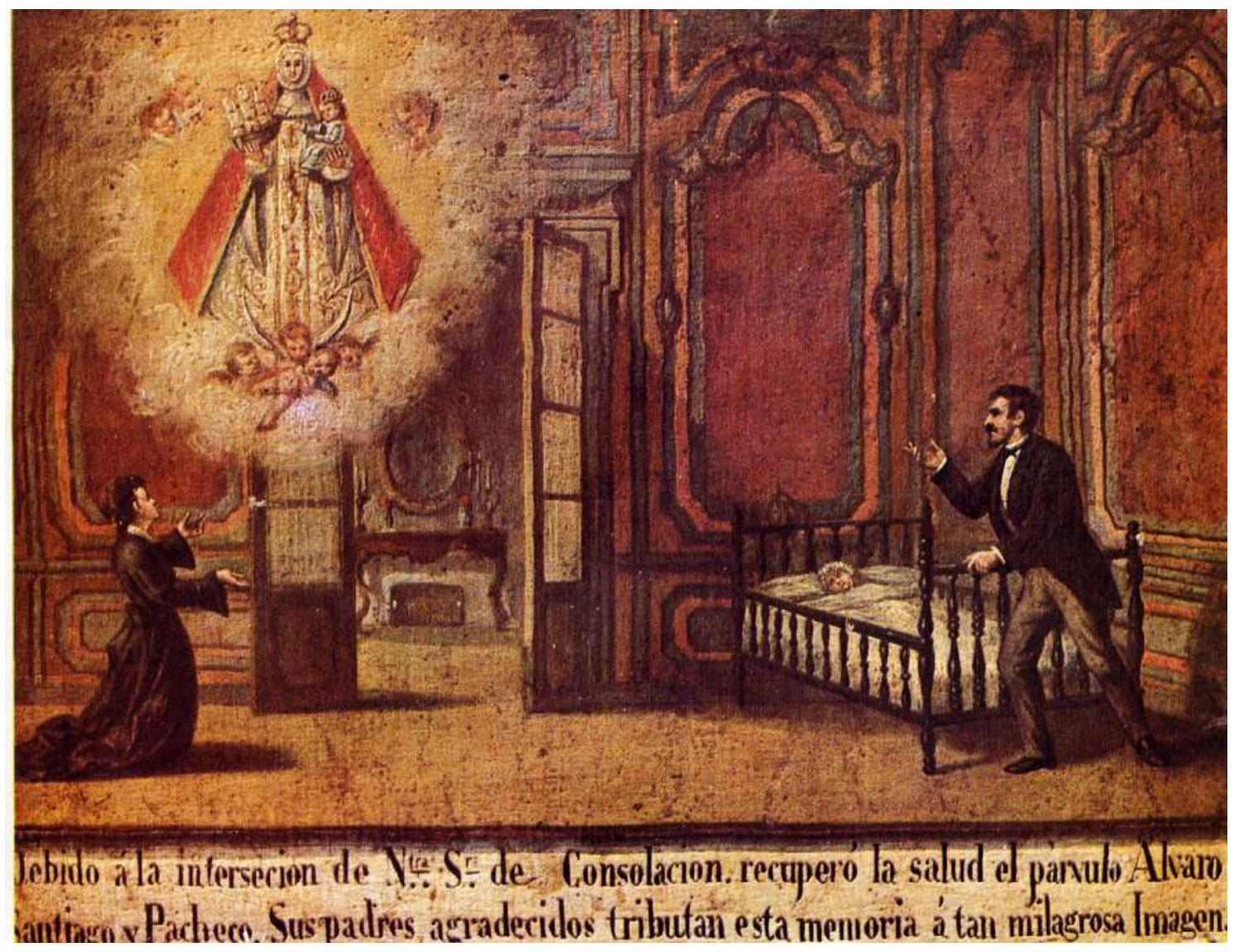

Fig. 11 Santuario de Nuestra Señora de Consolación. Utrera (Sevilla) 
Una excepción se encuentra en el interior burgués de un exvoto dedicado a la Virgen de Consolación de Utrera (Sevilla). De ejecución más cuidada, con cierto conocimiento de perspectiva, posiblemente encargado a algún artista local por una familia adinerada. (fig. 11) Aunque la pintura corresponde a la primera mitad del siglo XIX, la decoración y el mobiliario pertenecen a la centuria anterior. Muestra un interior casi palaciego, donde sus dueños presiden el centro de la composición, implorando la intercesión de la Virgen para que cure a su hijo pequeño que yace en una cuna de barrotes torneados. La pintura muestra en una estancia amplia, cuyas paredes están decoradas con paneles decorativos con molduras que forman un zócalo y registros rectangulares, decorados en la parte superior con guirnaldas, tipo boiseries, con efectos polícromos en colores oscuros, que enfatizan la altura de la habitación. A través de la gran puerta de dos hojas de la habitación se deja ver parte de un salón presidido por una consola rococó de patas formadas por curvas y contracurvas de motivos vegetales, con el frontal decorado por una venera o mascarón. Sobre la consola un gran espejo oval de marco dorado y tallado flanqueado por dos candelabros, conforman un interior rococó, donde la única excepción es la de la cuna que responde a modelos más tardíos.

Como se ha señalado anteriormente, ya sea en la sala o en el dormitorio, la silla juega un papel protagonista. Los asientos se alinean junto a las paredes en un número considerable. Una de las características más típicas del siglo XIX es la creación constante de los llamados muebles arquetipo, es decir, muebles que por la repetición de un modelo había llegado a convertirse en muebles atemporales que aún hoy en día se siguen utilizando. Los ejemplos más habituales de estos muebles son las sillas, que adaptan el respaldo a las distintas modas.

Las recogidas en los exvotos más antiguos reproducen modelos ingleses o franceses de la segunda mitad del XVIII, con el respaldo calado, el asiento tapizado y las patas cabriolé muy pronunciadas, pero interpretados con mucha libertad. No obstante, lo más frecuente es que se representen sillas sencillas, tanto en ámbitos burgueses como en viviendas más humildes, repitiéndose los modelos con asientos de enea, donde los respaldo suelen estar formados por un palillaje que tampoco varía mucho de unos modelos a otros. Muy populares fueron las sillas "de Vitoria”, llamadas así durante los años treinta y cuarenta, las de asiento de paja, mientras que a las tapizadas se las seguirá denominando taburetes. ${ }^{21}$ La silla "de Vitoria" es una tipología específica que tuvo una amplísima difusión desde fines del siglo XVIII, siendo las más sencillas las de tres palos en el respaldo y vástagos verticales torneados. Su alto consumo justifica la existencia de talleres silleros, que se mantienen desde el siglo XVIII, principalmente en la capital alavesa, en donde empezó su producción a imitación de los talleres franceses. ${ }^{22}$ Estas sillas, desde principios del siglo XIX se exportaban a toda la península, contabilizándose ocho talleres dedicados exclusivamente a la producción de sillas y canapés de diferentes calidades, surgiendo rápidamente talleres por toda España imitando los modelos vascos. A pesar del éxito que tuvo, a partir de la segunda mitad del siglo XIX quedó relegada a los hogares más humildes. Sus respaldos con palas centrales se inspiran en modelos ingleses, a menudo del estilo Sheraton, con palas caladas, palos torneados verticales, que se imponen durante los años cuarenta, normalmente en madera en su color. 
La mecanización de modelos que se repiten con insistencia dio como resultado que muchos muebles de asiento deriven en piezas sin gran relevancia. Fueron frecuentes también en esos años las largas banquetas o canapés, de tradición dieciochesca, de varias plazas arrimadas a la pared, como se aprecia en varios de los exvotos estudiados. (fig. 12)

En el estilo isabelino se busca el confort por lo que el tapizado es la novedad más importante en los asientos para una mayor comodidad, como los brazos de los sillones que se almohadillan, buscando el mencionado bienestar. En un primer momento los respaldos son planos para, finalmente, adoptar formas ovales, casi siempre sin tallas, propiciando un modelo sencillo y elegante que caracterizó los asientos de ese período. Por último, hay que señalar que a pesar del desarrollo que tuvo en el período isabelino, la consola y la pequeña mesa denominada velador, rara vez aparecen representados en los exvotos, lo que avala que fue un mueble de lujo, destinado a la burguesía.

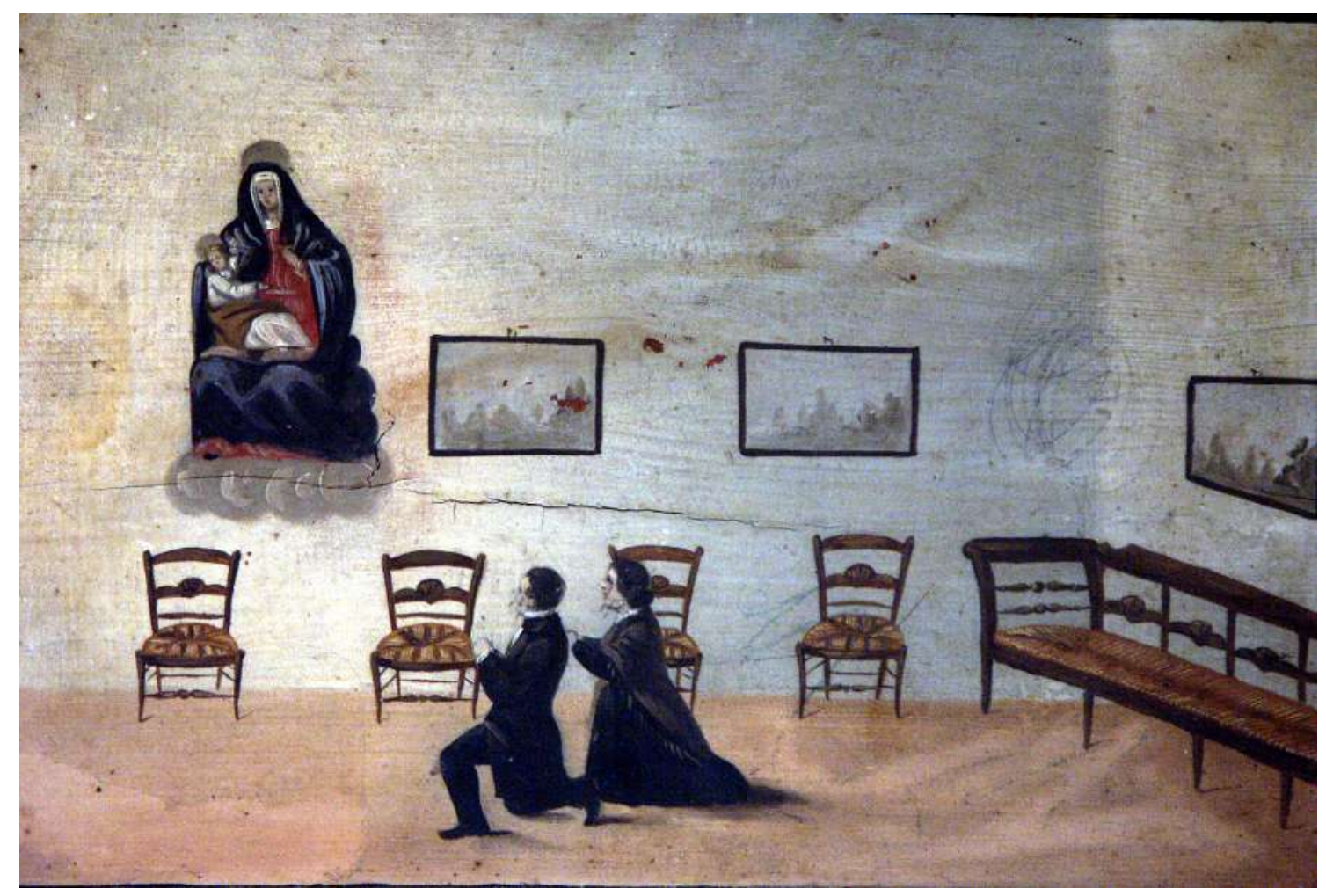

Fig. 12 Santuario de Nuestra Señora de Gracia. Archidona (Málaga)

\section{Conclusiones}

Se puede afirmar que el eclecticismo es el triunfador dentro de los interiores domésticos andaluces que se reflejan en los exvotos analizados, donde conviven muebles de diferentes épocas y donde la huella de un estilo puede extenderse a lo largo de los años, aunque lentamente las modas se irán imponiendo con carácter retardatario. En líneas generales y desde una perspectiva histórica, parece como si el siglo XIX hubiera sido incapaz de desatar sus lazos con el pasado y mirar hacia adelante. A esto contribuyó sin duda la irrupción 
de una nueva clase burguesa en los puestos dominantes de la sociedad, una clase que carecía de los conocimientos o la confianza necesaria en sí misma para elegir nuevas propuestas estilísticas, y por ello mismo optó por lo ya aceptado y aprobado, por el pasado como un refugio seguro, pero que serían un referente para las clases populares.

Los exvotos analizados son documentos cargados de información y que, gracias a esta práctica de religiosidad popular se puede conocer toda una serie de cuestiones de lo más plural en una época determinada, reflejo del nivel socioeconómico de la persona que los encargó. En definitiva, podemos afirmar que los exvotos son una fuente imprescindible para comprender histórica y culturalmente una época. Nunca una investigación queda del todo cerrada pues es necesario comparar el mobiliario representado en los exvotos andaluces con otras áreas peninsulares donde también fueron muy frecuentes estas manifestaciones populares, caso de Galicia, Aragón y Cataluña, y así poder plantear una comparativa tipológica y decorativa de los interiores domésticos populares.

\section{NOTAS}

${ }^{1}$ Una obra pionera e imprescindible en el estudio del mueble popular es la de Manuel Jorge Aragoneses, El mueble popular de Murcia (1866-1933), (Murcia: Real Academia Alfonso X el Sabio, 1982).

${ }^{2} \mathrm{M}^{\mathrm{a}}$ Isabel Álvaro Zamora, "Notas para el estudio del mueble popular: Lo culto y lo popular en el mobiliario pirenaico," en Etnología y tradiciones populares v. 2, ed. Institución Fernando el Católico (Zaragoza: Institución Fernando el Católico, 1987), 29-40.

${ }^{3}$ Pionera en analizar el mobiliario a través de la pintura fue $\mathrm{M}^{\mathrm{a}}$ Paz Aguiló. Al respecto véase Ma Paz Aguiló Alonso. "El mobiliario en la pintura del Siglo de Oro," Galería Antiquaria 91 (1992): 36-45.

${ }^{4}$ Un estudio muy completo sobre la religiosidad popular en España es la obra coordinada por Carlos Álvarez Santaló, La religiosidad popular: Hermandades, romerías y santuarios (Barcelona: Anthropos, 1989).

${ }^{5}$ La Ley de Patrimonio Histórico Español de 1985, en sus artículos 46 y 47 recoge el valor etnográfico de los exvotos. Asimismo, el Código de Derecho Canónico en el canon 1.234 incide que los exvotos deben conservarse y custodiarse con seguridad. A pesar de ello, al considerarse obras menores, se han degradado o perdido un número importantísimo de ellos.

${ }^{6}$ El tema de los exvotos en Andalucía desde un punto de vista antropológico ha sido ampliamente estudiado por Salvador Rodríguez Becerra a cuyos textos remito. Entre ellos puede consultarse la obra, en colaboración con J. M. Vázquez Soto, Exvotos de Andalucía. Milagros y promesas en la religiosidad popular (Sevilla: Argantonio, Ediciones Andaluzas, 1980).

${ }^{7}$ Los exvotos simbólicos son muy variados pues, a través de un objeto material, hacen alusión al favor recibido. Los más frecuentes suelen ser representaciones de diferentes partes del cuerpo, ejecutadas en cera o metal, que aluden a la parte del cuerpo sanada. También son frecuentes otros objetos como muletas, trenzas de pelo, corsés, uniformes militares, etc., objetos que ya no son necesarios después de la curación por la que se ha pedido el favor.

${ }^{8}$ Alfredo J. Morales y Juan Miguel Serrera, Exvotos de Andalucía (Sevilla: Cajasol, 1982): 19-35.

${ }^{9}$ Salvador Rodríguez Becerra, "Exvotos de Andalucía. Perspectivas antropológicas," Gaceta de Antropología 4 (1985).

${ }^{10} \mathrm{M}^{\mathrm{a}}$ Dolores Aguilar García, "Exvotos marianos de pintura ingenua," Baética 1 (1978): 5-42 
${ }^{11}$ Carmen de la Torre Lucena, "El espacio privado en España durante el siglo XIX," en Diseño de interiores y mobiliario. Aportaciones a una historia y estrategias de valoración, coord. María Teresa Sauret Guerrero, Nuria Rodríguez Ortega y Rafael Sánchez-Lafuente Gemar (Málaga: Publicaciones y Divulgación Científica, Vicerrectorado de Investigación y Transferencia de la Universidad de Málaga 2014): 255.

${ }^{12}$ Según el área geográfica los exvotos reciben también el nombre de milagros, milagritos, promesas, ofrendas, cuadros, votos, etc.

13 “Cartas sobre el viaje de España," en Viajes de extranjeros por España y Portugal v.V, ed. Jose Garcia Mercadal., (León: Junta de Castilla y León, Consejería de Educación y Cultura, 1999): 92 ${ }^{14}$ Sofía Diéguez Patao, "El espacio doméstico Contemporáneo: Un siglo de innovaciones," La casa. Evolución del espacio doméstico en España v. 2. (Madrid: Ediciones El Viso, 2006): 118.

${ }^{15}$ Sofía Rodríguez Bernis, Diccionario de mobiliario. (Madrid: Ministerio de Cultura, 2006): 83

${ }^{16}$ Mónica Piera,y Albert Mestres, El mueble en Cataluña. El espacio doméstico del Gótico al Modernismo (Barcelona: Fundació Caixa Manresa, 1999): 149.

${ }^{17}$ José Almuedo Palma, Ciudad e industria, Sevilla 1850-1930 (Sevilla: Diputación Provincial, 1996).

${ }^{18}$ Edward Lucie-Smith, Breve Historia del Mueble (Barcelona: Ediciones del Serbal,1988): 134.

${ }^{19}$ Sofía Rodríguez Bernis, "Mobiliario y decoración en Madrid durante el período Isabelino. Apuntes para un estudio," Museo Romántico 2, (1999): 31-48.

${ }^{20}$ En la misma ermita se conservan otros dos exvotos donde se reproduce idéntico escenario y escasas diferencias, pero de ejecución mucho más torpe y descuidada. Están fechados en 1815 y 1830 y otro de 1805.

${ }^{21}$ Rodríguez Bernis, "Mobiliario y decoración ...", 41.

${ }^{22}$ Donato Alfaro Martín, "Silla de Vitoria: origen y difusión de un asiento popular," Además de: revista on line de artes decorativas y diseño 5, (2019): 71-84. 